\title{
El documento: mucho más que un medio de comunicación
}

\section{Francisco Javier García Marco}

E-mail: jgarcia@posta.unizar.es

La tradicional afiliación teórica de las Ciencias de la Documentación a las Ciencias de la Comunicación ha centrado el problema de la información documental entorno a la cuestión comunicativa. El proceso documental se vislumbra desde este punto de vista - y de forma extremadamente acertada - como un proceso de comunicación, que se enfoca específicamente dentro de los parámetros del paradigma clásico de la comunicación propuesto por Shannon y Weaver (1949).

Un concepto clave de la teoría de la comunicación es, sin duda, el concepto de medio o canal. Este concepto nos permite situar mucho mejor el documento dentro del panorama de la comunicación humana. El documento es efectivamente, como ha señalado el profesor López Yepes, la fijación de un mensaje en un soporte, $\mathrm{y}$, en definitiva, un canal permanente que permite superar las limitaciones de la comunicación presencial. El documento, es por tanto, una tecnología, una herramienta, que permite crear canales de comunicación artificiales que mejoran en diferentes dimensiones — según su énfasis tecnológico- las posibilidades de la comunicación presencial.

Sin embargo, hoy queremos utilizar las dos páginas de editorial de la revista Scire para señalar que la Teoría de la Comunicación, aun siendo tan fructífera como es para iluminar el problema del documento, puede funcionar también a modo de "anteojeras epistemológicas" y ocultar ciertas realidades que, precisamente en el momento actual, están cobrando una importancia radical.

Ciertamente, el documento es mucho más que un medio de comunicación. El documento es un instrumento de memoria y, en definitiva, un creador de experiencias. Desde este punto de vista, el problema del documento debe insertarse dentro del marco más amplio del procesamiento humano de la información —el llamado paradigma cognitivo-, que no se limita al fascinante mundo de la 
comunicación, sino que incorpora los conceptos de la adaptación al medio, de la transformación del ambiente, del comportamiento autónomo, de la sensación, la percepción, el sentimiento, la memoria, el razonamiento y la imaginación ..., en definitiva, de la experiencia.

Es importante insistir en estos aspectos porque en los últimos años la función experiencial del documento está cobrando cada vez mayor importancia poniendo en cuestión las visiones tradicionales de nuestro objeto científico. Durante cerca de un siglo la teoría de la documentación se ha centrado — para construir su modelo del documento y del proceso documental—en el documento científico y, particularmente, en sus modalidades textuales. Sin embargo, la revolución multimedia exige una revisión del concepto tradicional de documento.

A raíz de los avances tecnológicos de los últimos siglos, se ha producido la convergencia entre la comunicación mediante imágenes — cada vez más realista—, y espacios arquitectónicos — cada vez más asombrosos- y el mundo de los mensajes verbales transliterados - escritos- A esta convergencia se ha añadido en el último siglo y pico la posibilidad de transmitir y guardar los mensajes orales y la imagen en movimiento.

En los últimos treinta años este proceso ha estallado en el medio ambiente tecnológico creado por la revolución de la información. De pronto, el horizonte mediato de los nuevos documentos es, ni más ni menos, la propia realidad virtual: mundos interactivos 'enlatados' donde el usuario puede acceder a formas de experiencia que se confunden con la realidad y en cuyos espacios coexisten, como en el ambiente natural, todo tipo de medios de comunicación.

Pues bien, en este volumen se presentan diversos trabajos que abordan la explosiva realidad de la 'nueva documentación' — la Internet como ámbito de construcción del saber universitario y como fuente de información estadística privilegiada, la realidad virtual como futuro de la interacción hombre-máquina, los documentos audiovisuales en la frontera del servicio documental en la industria, la organización de los espacios conceptuales en el hiperespacio como reto ineludible-, todo ello enriquecido por la cada vez mejor sistematizada tradición científica en nuestro campo, ejemplificada en este número con excelentes trabajos sobre la normalización de las descripciones documentales o la teoría del análisis temático y sus fundamentos terminológicos y lingüísticos.

Zaragoza, a 30 de diciembre de 2000. 